ISSN 0258-7122

Bangladesh J. Agril. Res. 38(2): 203-209, June 2013

\title{
PERFORMANCE OF BARI MANGO (Mangifera indica L.) VARIETIES IN CHITTAGONG REGION
}

\author{
H. BARUA ${ }^{2}$, M. M. AlaM PATWARY ${ }^{1}$ AND M. H. RAHMAN ${ }^{2}$
}

\begin{abstract}
Five mango varieties developed by Bangladesh Agricultural Research Institute (BARI) were evaluated at ARS, Pahartali, Chittagong during January to June 2012 to find out the suitable variety. The earliest flowering as well as harvesting were observed in BARI Aam-1 and the latest in BARI Aam-8. Number of fruits per tree varied from 51 to 117. Maximum number of fruits (117) per tree was obtained from BARI Aam-8, while minimum fruits (51) from BARI Aam-4 (Hybrid). The heaviest fruit (373.0 g) was obtained from BARI Aam-4 (Hybrid), while the lightest fruit (172.6 g) was in BARI Aam-3. Maximum yield per plant was found in BARI Aam-8 (33.59 kg) followed by BARI Aam-4 (19.02 kg), whereas it was lowest in BARI Aam-1(14.42 kg). The highest edible portion $(78.66 \%)$ was recorded in BARI Aam-4, while the lowest $(65.99 \%)$ was obtained from BARI Aam-1. The highest TSS content $(21.36 \%)$ was recorded in BARI Aam-3, whereas the lowest TSS content (16.51\%) was observed in BARI Aam-2.
\end{abstract}

Keywords: Growth, flowering, fruit characteristics, mango.

\section{Introduction}

Mango (Mangifera indica L.), a tropical and sub-tropical fruit, belongs to the family Anacardiaceae, which was originated in South Asia/Malayan archipelago and has been in cultivation for more than 4000 years (Mukherjee, 1949; Candole, 1984; Bose, 1985). It is an important and popular fruit in the world for its excellent flavours, attractive colour, delicious taste, and high nutritive value. In Bangladesh, it occupies an area of 32011 hectares of land with an annual production of 1047849 metric tons (BBS, 2011).

Although it grows well in all parts of Bangladesh, the grafted mango plants are concentrated in a few places in the north western region and seedling mangoes are grown in the southern and other parts of Bangladesh (Bhuyan, 1995). But the scenario has changed to some extent in recent years. Some elite farmers have taken keen interest to establish commercial orchard for mango with grafted mango plants in southern region, especially in the hilly areas and Chittagong Hill Tracts. Bangladesh Agricultural Research Institute (BARI) has already released 10 (ten) mango varieties with variable quality. In general, the cultivars are location specific and the commercial varieties of one region may not

${ }^{1}$ Senior Scientific Officer, ${ }^{2}$ Scientific Officer, Agricultural Research Station, Pahartali, Chittagong, Bangladesh. 
do so well when grown in other areas (Majumder et al., 2001). Information regarding the performances of the released mango varieties is scanty under Chittagong condition. Therefore, the present investigation was undertaken to evaluate the performance of mango varieties developed by BARI under hot and humid climatic condition of Chittagong region.

\section{Materials and Method}

The experiment was conducted at the Agricultural Research Station, Pahartali, Chittagong during 2011-2012. Five released mango varieties, namely BARI Aam-1, BARI Aam-2, BARI Aam-3, BARI Aam-4 (Hybrid), and BARI Aam-8 were included in this study. The experiment was laid out in randomized complete block design (RCBD) with three replications. The saplings were planted on July 2004 with a spacing of $8 \mathrm{~m} \times 8 \mathrm{~m}$. A single tree of each variety constituted the unit of replication. The trees were fertilized as per schedule described by Hossain (1989). Ripcord 10 EC@ 1 ml along with Dithane M- $45 @ 2$ g per litre of water was sprayed with the help of a power sprayer at panicle emergence (before anthesis) and pea stage of fruits to control mango hoppers and anthracnose as per recommendation of Hossain (1989). Fertilizers were applied twice in a year on 29 June and 25 September 2011. Irrigation was done at pea stage of fruit on 10 April 2011. Other intercultural operations, such as weeding, ploughing, and mulching were done as and when necessary. Girth of the trunk was measured at a height of $15 \mathrm{~cm}$ from ground level and tree volume was calculated following formula by Castle (1983) with some modifications, such as $\pi / 6 \mathrm{X}$ height $\mathrm{X}(2 \mathrm{r})^{2}$ where, $2 \mathrm{r}=($ East - West + North - South canopy spread $) / 2$. Data on plant height, canopy of the tree, flowering and harvesting, fruit weight, number of fruits per tree, TSS content, edible portion, fruit size, stone size and stone weight were recorded. All the data were recorded following mango descriptor recommended by IBPGR (2006). Organoleptic evaluation was done and for this, a panel of five members were selected to determine the pulp colour, sweetness, aroma, texture, juiciness, fibrousness, peeling quality, eye appeal, and general quality of fruits of different genotypes based on the criteria of the score card as follows : a) Pulp colour: 1- light yellow, 2- yellow, 3- bright yellow; b) Sweetness/Taste: 1insipid, 2- sweet, 3- very sweet; c) Aroma: 1- very slight, 2- pleasant, 3delightful; d) Texture: 1- firm, 2- medium, 3- soft; e) Juiciness: 1- scantly, 2much, 3- abundant; f) Fibrousness: 1- abundant, 2- much, 3- scanty; g) Peeling quality: 1- hard, 2- medium, 3- easy, and h) Eye appeal: 1- poor, 2- good, 3- very good (Uddin et al., 1998). Data on insect pest and diseases were also recorded at fruit harvest. Data were analyzed statistically and the means were separated by LSD following MSTATC software. 


\section{Results and Discussion}

Results of the study are presented in Table 1, 2, 3, and 4. The investigation revealed that growth of mango varieties varied significantly for all the parameters (Table 1). The widest base girth $(49.92 \mathrm{~cm})$ was produced by BARI Aam-1, whereas the narrowest $(35.36 \mathrm{~cm})$ by BARI Aam-3. Highest plant height was observed in BARI Aam-8 $(4.81 \mathrm{~m})$ followed by that of BARI Aam-1 $(4.52 \mathrm{~m})$, while the lowest in BARI Aam-3 $(3.90 \mathrm{~m})$. Tree volume was maximum (42.33 $\left.\mathrm{m}^{3}\right)$ in BARI Aam-8 followed by that in BARI Aam-1 $\left(40.55 \mathrm{~m}^{3}\right)$ and it was minimum in BARI Aam-3 $\left(31.21 \mathrm{~m}^{3}\right)$. The other varieties had intermediate tree volume. The flowering of all the varieties took place in between 23.02.2012 and 07.03.2012. The earliest flowering at 23 February was produced by BARI Aam1, while the latest flowering at 07 March by BARI Aam - 8. The variability in relation to flowering found in the present study is in agreement with the findings of Valmayor (1962) who reported that the variation of blooming period was dependent upon the combination of environmental factors and the condition of the plant. The harvesting period varied from 08 May to 22 July. Among the varieties, the fruits of BARI Aam-1 matured on 08 May, while the fruits of BARI Aam- 4 matured on 22 June. Other varieties were intermediate in fruit maturity. The result supports the findings of Hossain (1989) who reported that fruits of mango mature within 4-6 months of flowering.

The heaviest fruit $(373 \mathrm{~g})$ was obtained from BARI Aam-4, whereas the lightest fruit (172 g) in BARI Aam-3 (Table 2). This variation might be due to genetic differences among the variety. Uddin et al. (2006) also reported variable fruit weight in different mango varieties. The longest fruit $(12.30 \mathrm{~cm})$ was obtained from BARI Aam-1. The highest fruit breadth $(9.18 \mathrm{~cm})$ and fruit thickness $(7.04$ $\mathrm{cm})$ were recorded from BARI Aam-4, while the lowest breadth $(6.24 \mathrm{~cm})$ and thickness $(5.50 \mathrm{~cm})$ were recorded from BARI Aam-3. Mollah and Siddique (1973) and Saha and Hossain (1988) also found different fruit sizes in different mango varieties. Number of fruits per tree varied from 51 to 117 . The highest number of fruits per tree (117) was obtained from BARI Aam-8, while the lowest number of fruits per tree (51) from BARI Aam-4 (Hybrid). The number of fruits per tree varied depending upon the variety (Singh, 1990). Fruit production per unit volume of tree was the highest $\left(3.52 / \mathrm{m}^{3}\right)$ in BARI Aam-3 and the lowest $\left(1.40 / \mathrm{m}^{3}\right)$ in BARI Aam-4. The highest yield $(33.59 \mathrm{~kg})$ per tree was produced by BARI Aam- 8 and the lowest yield (14.42 kg) was recorded from BARI Aam-1.The heaviest stone $(50.8 \mathrm{~g})$ was recorded in BARI Aam- 4 , whereas the lightest stone $(29.2 \mathrm{~g})$ in BARI Aam-3 (Table 3). The longest $(10.11 \mathrm{~cm})$ and the shortest (6.76 $\mathrm{cm})$ stones were produced in BARI Aam- 8 and BARI Aam-1, respectively. The widest $(5.23 \mathrm{~cm})$ and the thickest $(2.27 \mathrm{~cm})$ stones were produced by BARI Aam- 8 and BARI Aam-2, respectively. Percent edible portion and percent TSS of fruits are the two most important criteria of quality mango. These were significantly 
different among the varieties. The highest edible portion (78.66 \%) was recorded in BARI Aam-4, while the lowest edible portion (65.99\%) was obtained from BARI Aam-1. The findings of the present study are in good agreement with that of Haque et al. (1993). The highest TSS content in fruit juice $(21.36 \%)$ was recorded in BARI Aam-3 followed by that in BARI Aam-4 (19.20\%). The lowest TSS (16.51\%) was observed in BARI Aam-2. The results are in conformity with Haque et al. (1993) who recorded 15.0, 20.0 and 19.0\% TSS in Badshabhog, Himsagar, and Bishawanath, respectively. During releasing varieties, the edible portion of BARI Aam-1, BARI Aam-2, BARI Aam-3, BARI Aam- 4 and BARI Aam- 8 were $70 \%, 69 \%, 71 \%, 80 \%$, and $70 \%$, respectively, while TSS content of these varieties were $19 \%, 17.5 \%, 23.4 \%, 24.5 \%$, and $22 \%$, respectively, under Nawabgonj condition. It indicates a slight decrease in percent edible portion and TSS content in the experimental site as compared to the original site of the varietal release. These deterioration might be due to the climatic variation between the experimental site of Chittagong with the original site of varietal release in Nawabgonj which is more favourable for mango cultivation.

Table 1. Tree growth, flowering and harvesting of five mango varieties.

\begin{tabular}{c|c|c|c|c|c}
\hline Variety & $\begin{array}{c}\text { Plant height } \\
(\mathrm{m})\end{array}$ & $\begin{array}{c}\text { Base girth } \\
(\mathrm{cm})\end{array}$ & $\begin{array}{c}\text { Tree } \\
\text { volume }\left(\mathrm{m}^{3}\right)\end{array}$ & $\begin{array}{c}\text { Date of } \\
\text { flowering }\end{array}$ & $\begin{array}{c}\text { Date of } \\
\text { harvesting }\end{array}$ \\
\hline BARI Aam -1 & 4.52 & 49.92 & 40.55 & 23.02 .2012 & 08.05 .2011 \\
BARI Aam -2 & 4.12 & 46.00 & 38.10 & 28.02 .2012 & 28.05 .2011 \\
BARI Aam -3 & 3.90 & 35.36 & 31.21 & 02.03 .2012 & 06.06 .2011 \\
BARI Aam- 4 & 4.05 & 38.00 & 36.33 & 05.03 .2012 & 22.06 .2011 \\
(Hybrid) & & & & & \\
BARI Aam -8 & 4.81 & 48.00 & 42.33 & 07.03 .2012 & 18.06 .2011 \\
\hline CV (\%) & 1.97 & 0.06 & 0.05 & - & - \\
LSD(0.05) & 0.14 & 0.05 & 5.55 & - & - \\
LSD $(0.01)$ & 0.20 & 0.07 & 8.08 & - & - \\
\hline
\end{tabular}

Table 2. Fruit characteristics and yield of five mango varieties.

\begin{tabular}{|c|c|c|c|c|c|c|c|}
\hline \multirow{2}{*}{ Variety } & \multirow{2}{*}{$\begin{array}{c}\text { Fruit } \\
\text { weight } \\
\text { (g) }\end{array}$} & \multicolumn{3}{|c|}{ Fruit size $(\mathrm{cm})$} & \multirow{2}{*}{$\begin{array}{c}\text { No. of } \\
\text { fruits/ } \\
\text { tree }\end{array}$} & \multirow{2}{*}{$\begin{array}{c}\text { Fruits/ } \\
\mathrm{m}^{3}\end{array}$} & \multirow{2}{*}{ Fruit colour } \\
\hline & & Length & Breadth & Thickness & & & \\
\hline BARI Aam -1 & 192 & 8.02 & 6.74 & 6.12 & 79 & 1.95 & Bright yellow \\
\hline BARI Aam -2 & 227 & 9.48 & 6.96 & 6.26 & 70 & 1.84 & Light yellow \\
\hline BARI Aam -3 & 172 & 9.36 & 6.24 & 5.50 & 110 & 3.52 & $\begin{array}{l}\text { Yellowish } \\
\text { green }\end{array}$ \\
\hline $\begin{array}{l}\text { BARI Aam- } \\
4 \text { (Hybrid) }\end{array}$ & 373 & 10.54 & 9.18 & 7.04 & 51 & 1.40 & $\begin{array}{l}\text { Yellowish } \\
\text { green }\end{array}$ \\
\hline BARI Aam- 8 & 314 & 12.30 & 7.12 & 6.52 & 117 & 2.76 & Bright yellow \\
\hline CV $(\%)$ & 13.25 & 8.64 & 4.12 & 9.99 & 8.34 & 5.21 & - \\
\hline $\operatorname{LSD}(0.05)$ & 7.74 & 0.12 & 0.78 & 0.51 & 18.46 & 0.12 & - \\
\hline $\operatorname{LSD}(0.01)$ & 11.26 & 0.17 & 1.10 & 0.75 & 26.86 & 0.17 & - \\
\hline
\end{tabular}


Table 3. Stone and other fruit characteristics of five mango varieties.

\begin{tabular}{|c|c|c|c|c|c|c|c|}
\hline \multirow[b]{2}{*}{ Variety } & \multirow{2}{*}{$\begin{array}{l}\text { Stone } \\
\text { weight } \\
(\mathrm{g})\end{array}$} & \multicolumn{3}{|c|}{ Stone size $(\mathrm{cm})$} & \multirow{2}{*}{$\begin{array}{c}\text { Edible } \\
\text { portion } \\
(\%)\end{array}$} & \multirow{2}{*}{$\begin{array}{c}\text { Yield } \\
/ \text { tree } \\
(\mathrm{kg})\end{array}$} & \multirow{2}{*}{$\begin{array}{l}\text { TSS } \\
(\%)\end{array}$} \\
\hline & & Length & Breadth & Thickness & & & \\
\hline BARI Aam -1 & 41.4 & 6.76 & 5.00 & 2.12 & 65.99 & 14.42 & 19.14 \\
\hline BARI Aam-2 & 35.0 & 7.32 & 4.26 & 2.27 & 69.25 & 15.92 & 16.51 \\
\hline BARI-Aam- 3 & 29.2 & 7.12 & 4.75 & 1.89 & 68.02 & 18.12 & 21.36 \\
\hline $\begin{array}{c}\text { BARI Aam- } 4 \\
\text { (Hybrid) }\end{array}$ & 50.8 & 8.92 & 5.18 & 2.22 & 78.66 & 19.02 & 19.20 \\
\hline BARI Aam -8 & 48.0 & 10.11 & 5.23 & 2.09 & 67.93 & 33.59 & 18.22 \\
\hline CV $(\%)$ & 0.30 & 8.15 & 6.25 & 9.28 & 11.25 & 12.35 & 6.88 \\
\hline $\operatorname{LSD}(0.05)$ & 0.20 & 0.36 & 0.10 & 0.08 & 1.68 & 1.46 & 1.46 \\
\hline $\operatorname{LSD}(0.01)$ & 0.29 & 0.53 & 0.15 & 0.12 & 2.45 & 2.12 & 2.13 \\
\hline
\end{tabular}

Table 4. Organoleptic characteristics of five mango varieties.

\begin{tabular}{c|c|c|c|c|c|c|c|c|c}
\hline Variety & $\begin{array}{c}\text { Pulp } \\
\text { colour }\end{array}$ & Taste & Aroma & Juiciness & $\begin{array}{c}\text { Fibrou/ } \\
\text { sness }\end{array}$ & $\begin{array}{c}\text { Peeling } \\
\text { quality }\end{array}$ & $\begin{array}{c}\text { Eye } \\
\text { appeal }\end{array}$ & $\begin{array}{c}\text { General } \\
\text { quality }\end{array}$ & $\begin{array}{c}\text { Mean } \\
\text { score }\end{array}$ \\
\hline $\begin{array}{c}\text { BARI } \\
\text { Aam-1 }\end{array}$ & 2.7 & 2.4 & 2.6 & 1.6 & 1.3 & 2.3 & 2.7 & 2.7 & 2.28 \\
BARI & 2.2 & 2.2 & 2.4 & 1.7 & 1.3 & 2.4 & 2.4 & 2.6 & 2.15 \\
Aam- 2 & & & & & & & & & \\
BARI & 2.9 & 2.9 & 2.3 & 1.9 & 1.1 & 2.5 & 2.3 & 2.8 & 2.33 \\
Aam -3 & & & & & & & & & \\
BARI & 2.4 & 2.6 & 2.3 & 1.9 & 1.2 & 2.6 & 2.7 & 2.9 & 2.32 \\
$\begin{array}{c}\text { Aam- } 4 \\
\text { (Hybrid) }\end{array}$ & & & & & & & & & \\
BARI & 2.1 & 1.9 & 2.5 & 1.8 & 2.2 & 2.4 & 2.4 & 2.5 & 2.22 \\
Aam-8 & & & & & & & & & \\
\hline Mean & 2.46 & 2.40 & 2.42 & 1.78 & 1.42 & 2.44 & 2.50 & 2.70 & \\
\hline
\end{tabular}

Organoleptic characteristics of five mango varieties are shown in Table 4. In respect of pulp colour, the highest score (2.9) was obtained from BARI Aam-3 followed by that of BARI Aam-1 (2.7) and the lowest from BARI Aam-8 (2.1). In respect of taste, BARI Aam-3 ranked the highest score (2.9) and the lowest (1.9) was in BARI Aam-2. BARI Aam-1 scored the maximum (2.6) in respect of aroma. In case of juiciness, the highest (1.9) score was found in BARI Aam-3 and BARI Aam-4 followed by that in BARI Aam-8 (1.8). Maximum fibre was found in BARI Aam-8 (2.2), while the lowest (1.1) was in BARI Aam-3 preceded by BARI Aam-4 (1.2). From the above result, it is revealed that BARI Aam-3 had the highest average mean score (2.33) followed by BARI Aam-4 
(2.32), while the lowest score (2.15) was found in BARI Aam-2. The present results are in accordance with the findings of Uddin et al., 2007 who mentioned the variable score in different mango genotypes. Fruit fly infestation was observed only in BARI Aam-3 (10\%) and BARI Aam-8 (4\%). On the other hand, stone weevil infestation was observed in BARI Aam-8 (20\%) and BARI Aam-3 (5\%). Fruit cracking was observed only in BARI Aam -3 (18\%) and BARI Aam$8(10 \%)$.

Table 5. Incidence of insect pest, disease and fruit cracking in five mango varieties.

\begin{tabular}{c|cc|c|c}
\hline \multirow{2}{*}{ Variety } & \multicolumn{2}{|c|}{ Insect infestation (\%) } & \multirow{2}{*}{$\begin{array}{c}\text { Fruit } \\
\text { anthracnose (\%) }\end{array}$} & $\begin{array}{c}\text { Physiological disorder/ fruit } \\
\text { cracking (\%) }\end{array}$ \\
\cline { 2 - 3 } & Fruit fly & Stone weevil & 0 & 0 \\
\hline BARI Aam- 1 & 0 & 0 & 0 & 0 \\
BARI Aam -2 & 0 & 0 & 3 & 18 \\
BARI Aam -3 & 10 & 5 & 4 & 0 \\
BARI Aam - & 0 & 0 & 0 & 10 \\
4(Hybrid) & 4 & 20 & 10 & 5.6 \\
BARI Aam -8 & 4 & 5 & 3.4 & \\
\hline Mean & 2.8 & &
\end{tabular}

\section{Conclusion}

Among the tested mango varieties, BARI Aam-1 was found superior considering earliness, fruit colour, and aroma without infestation by insect pest and diseases, while BARI Aam-3, BARI Aam-4 (Hybrid), and BARI Aam- 8 were also found suitable for cultivation in Chittagong region with minimum infestation by insect pests and diseases.

\section{References}

BBS (Bangladesh Bureau of Statistics). 2011. Yearbook of Agricultural Statistics of Bangladesh 2010. Bangladesh Bureau of Statistics, Statistics Division, Ministry of Planning, Government of the People's Republic of Bangladesh. p. 136.

Bhuyan, M. A. J. 1995. Mango (Mangifera indica). In: Fruit productiuon manual. Hort. Res. Dev. Proj. (FAO/UNDP/AsDB project: BGD/87/025). p. 197.

Bose, T. K. 1985. Fruits of India: Tropical and Sub-tropical. Naya Prokash, India, p. 91.

Candole, A. D. 1984. Origin of Cultivated Plants. Vegal Paul Trench and Co. London, Pp. 1-67.

Castle, S. W. 1983. Growth, Yield and Cold Hardiness of seven year old "Bears" Lemon trees on twenty seven rootstock. Proc. Fla. State Hort. Soc. 96:23-25.

Haque, A. M. M. M, M. R. Ali, M. R. Uddin, and A. K. M. A. Hossain.1993. Evaluation of elite mango cultivars at southern region of Bangladesh. Bangladesh J. Plant Breed. Genet. 6(2):21-28. 
Hossain, A. K. M. A. 1989. Manual on Mango Production in Bangladesh. Div. of Hort., Bangladesh Agricultural Research Institute, Gazipur. Pp.10-64.

IBPGR. 2006. Descriptors for Mango. International Board of Plant Genetic Resources, Rome Italy. P. 9.

Majumder, P. K., D. K. Sharma and D. Sanyal. 2001. Mango. In: Fruits: Tropical and Subtropical. $3^{\text {rd }}$ edn. Vol. 1. (Eds. T. K. Bose, S. K. Mitra and D. Sanyal), Naya Udyog, 206, Bidhan Sarani, Calcutta, India. P. 68.

Mandal, M. R. I., M.S. Alam, M. A. J. Bhuyan, M. M. Rahman and M. H. H. Rahman (Eds.). 2011. Krishi Projukti Hatboi. $2^{\text {nd }}$ part. $5^{\text {th }}$ edn. Bangladesh Agricultural Research Institute, Gazipur, 1701. Bangladesh. Pp. 3-10.

Mollah, S. and M. A. Siddique. 1973. Studies on some mango varieties of Bangladesh. Bangladesh Hort. 1(2): 16-24.

Mukherjee, S. K. 1949. Mango and its Relatives. Sci. Cult. 15: 5-9.

Saha, A. K. and A. K. M. A. Hossain. 1988. Studies on fruit characteristics of some grafted mango cultivars. Bangladesh J. Agric. Res. 13(2):47-52.

Singh, R. N. 1990. Mango. Indian Council of Agricultural Research, New Delhi. Pp.46-65.

Uddin, M. S., M. M. A. Patwary and M. A. Salam. 1998. Growth, flowering behaviour and fruit characteristics of promising mango lines. Bangladesh Hort. 26 (1\&2): 41-44.

Uddin, M. Z., M. A. Rahim, J. C. Barman and M.A Wadud. 2006. A study on the physical characteristics of some mango germplasm grown in Mymensingh condition. Int. J. Sustain. Crop Prod. 1(2): 33-38.

Uddin, M. Z., M. G. Mortuza, M. A. Alam, M. S. Islam and M. S. Uddin. 2007. Performance of some commercial and promising mango varieties. J. Bangladesh Soc. Agric. Sci. Technol. 4(1\&2): 105-108.

Valmayor, R. V. 1962. The Mango, its Botany and Production. University of the Phillippines, Los Banos, Laguna, Phillippines. P.120. 